Volume 5, Issue 2

September 2012

\title{
'Strange Visitor From Another Planet': : Genre, Corporate Identity and the Arrival of American Telefantasy on British Television
}

\author{
DEREK JOHNSTON, Queen's University, Belfast
}

\begin{abstract}
While the BBC had been broadcasting television Science Fiction productions from as early as 1938, and Horror since the start of television in 1936, American Telefantasy had no place on British television until ITV's broadcast of Adventures of Superman (1952-1958) in 1956. It would be easy to assign this absence to the avoidance of popular American programming, but this would ignore the presence of Western and adventure serials imported from the US and Canada for monopoly British television. Similarly, it would be inaccurate to suggest that these imports were purely purchased as thrilling fare to appease a child audience, as it was the commercial ITV that was first to broadcast the more adult-orientated Science Fiction Theatre (1955-7) and Inner Sanctum (1954). This article builds on the work of Paul Rixon and Rob Leggott to argue that these imports were used primarily to supply relatively cheap broadcast material for the new channel, but that they also served to appeal to the notion of spectacular entertainment attached to the new channel through its own productions, such as The Invisible Man (1958-1959) and swashbucklers such as The Adventures of Robin Hood (1955-60). However, the appeal was not just to the exciting, but also to the transatlantic, with ITV embracing this conception of America as a modern place of adventure through its imports and its creation of productions for export, incorporating an American lead into The Invisible Man and drawing upon an (inexpensive) American talent pool of blacklisted screenwriters to provide a transatlantic style and relevance to its own adventure series. Where the BBC used its imported serials as filler directed at children, ITV embraced this transatlantic entertainment as part of its identity and differentiation from the BBC.
\end{abstract}

\section{KEYWORDS}

Americanisation, British television, Science Fiction, Telefantasy, television history. 
Volume 5, Issue 2

September 2012

\section{Introduction}

American Telefantasy has long been a key part of the British television landscape, whether that be through programmes such as Lost (2004-2010), Stargate SG-1 (1997-2007) and its spin-offs, Buffy the Vampire Slayer (1997-2003), The X-Files (1993-2002), Knight Rider (1982-1986, 2008), The Six-Million Dollar Man (1974-1978) or Lost in Space (1965-1968). These shows have been transmitted, repeated, been subject to nostalgic revivals, loved and reviled. They have formed significant parts of early-evening BBC2 schedules, showing various incarnations of Star Trek as well as Buffy the Vampire Slayer throughout the 1980s and '90s. Telefantasy has been so central to Sky One's programming that the revived Battlestar Galactica (2003-2009) was part-funded by the channel after a succession of prematurely cancelled Telefantasy series such as Crusade (1999), Tru Calling (2003-2005), Jake 2.0 (2003-2004) and Firefly (2002-2003) left gaps in the Sky One schedule. This article, however, examines the earliest appearances of American Telefantasy in Britain in the 1950s, demonstrating how they fitted into cultural concerns of the period, but also how they fitted as part of the process of differentiation between the two television broadcasters at the time. This demonstrates the cultural shifts which would help make these more modern programmes such an important part of British television.

As there were no imports of recorded American Telefantasy into Britain before ITV began broadcasting in 1955, it would be easy to assume that this is a case of the patriarchal BBC "protecting" its viewers from the pernicious effects of American television. However, as we shall see, the $\mathrm{BBC}$ had been importing American entertainment on film since very early in the existence of the television service, as perhaps most famously demonstrated by the fact that it was a Mickey Mouse cartoon that was unceremoniously cut off by the abrupt shutting down of the Alexandra Palace transmitter at the outbreak of the Second World War. The BBC had also been responsible for Telefantasy productions since the very first night of scheduled television broadcasts, 2 November 1936. So it was neither nationality nor genre nor medium that prevented the $\mathrm{BBC}$ from broadcasting American filmed Telefantasy. However, these factors together, in their historical and industrial context, meant that the Corporation was inclined to emphasise and utilise other programming, domestically produced, performed live in a studio, and only occasionally falling into the Telefantasy category. This also meant that the use of American filmed Telefantasy by ITV would be, in part, driven by a simple need to fill programming hours, but also by a desire on the part of the commercial broadcaster to differentiate themselves from the BBC by embracing the popular, modern style of the American filmed series.

This article examines the historical and industrial context of the arrival of American Telefantasy on British television, building upon the work of, amongst others, Paul Rixon (2006) in exploring the ways that American television programming has been used on British television. Rixon argues that American television programmes are used on British screens not as part of a culturally imperialist agenda on behalf of US television producers, but that they are assimilated into their new British cultural and televisual context. In a sense, they are no 
longer American programmes on British television, but American-British programmes. This viewpoint suggests an active viewer who is also the recipient of 'inbuilt meanings and values' (Rixon, 2006: 2), creating a 'more dynamic' (Ibid.) relationship between viewer and text than either the hypodermic model or the active viewer model. However, Rixon does not concentrate on the programme-viewer relationship in his research, but instead focuses on the reframing or 're-encoding' that is performed by the broadcaster before the production in question is ultimately received by the viewer, active or not (Ibid.: 24-26). He emphasises that the role of the broadcaster in selecting and mediating productions is an active one, albeit one informed and influenced by 'by the wider socio-ideological-economic industrial context and discourses' (Ibid.: 83); as he emphasises, 'forces do not buy programmes, broadcasters do' (Ibid.). It is this line of the research that this article develops, considering the BBC and ITV as active framers of television texts produced domestically and in the United States.

As such, this article argues that the ITV companies, to some extent, embraced the thenpopular understanding of American popular culture in mid-1950s Britain as part of their way of differentiating themselves from the existing BBC Television Service. However, this was a modified form of Americanism, as it was framed and modified by the British - particularly, regional - identities of the ITV broadcasters. The dynamics of this relationship are made clear in a number of Science Fiction productions of this early-ITV period, both in their use by ITV broadcasters to provide a sense of "American" excitement, and also by the production of "Americanised" programmes in Britain, such as The Adventures of Robin Hood (1955-60), which not only used modified versions of American-style television formats and aesthetics, but which were also intended for export to various territories, including the US.

This fits with Rob Turnock's argument that developments in British culture in the late-1950s 'marked an apparent cultural shift from a Britain characterized by postwar austerity and consensus to a society marked by consumer culture, social fragmentation and individualism' (Turnock, 2007: 2), with these characteristics popularly perceived at the time as being aspects of American culture, rather than British. However, it was not so much a desire to copy America, but more a move towards a new, modern era which was most clearly symbolised by conceptions of the United States. Generally, people did not want Britain to become exactly like the US; however, there was a perception that the United States was more modern than Britain, and there was a desire to take on some of the characteristics of that more modern society. Turnock argues that television in this period became established as having 'the power to promote change and define social experience' (Ibid.: 7, italics in original). One of the ways that this was done was through the selection of programming, as well as the uses of particular television styles and genres, as the remainder of this article explores.

\section{American Television on British Television}

While British television had the potential advantage of being the first regular high-definition television service in the world, beginning in 1936, it was rapidly followed by developments 
Volume 5, Issue 2

September 2012

in other countries. These developments continued during the period that the BBC Television Service was off the air for the duration of the Second World War, closing down in 1939. So when the service began its transmissions again in 1946, it had lost its lead in the global development of television.

Popular histories of television make it easy to take away the impression that British television during the period of the BBC monopoly was largely dull and entirely home-produced. Even a documentary by the BBC itself, Children's TV on Trial (2007), depicted BBC monopoly television as boring, paternalistic and outdated, presented live by smartly-dressed "uncles" and "aunties" with cut-glass accents from limited studio sets. This boredom would be replaced by excitement with the launch of ITV, which brought with it fast-paced American Westerns and adventure series made on film. Such ideas seem fairly convincing, if it were not for the fact that the BBC had been showing American and Canadian filmed series and serials since the 1940s, including Westerns and Mountie movies, with 57 Westerns broadcast in 1948 alone (Boyd, 2011: 240). We have already mentioned the use of Disney cartoons during the 1930s, which itself indicates that the BBC was not averse to popular entertainment programming even in its earliest years.

Indeed, while ITV's listings magazine TV Times may have featured American import I Love Lucy (1951-1957) on its front cover, and the Television Annual for 1957 may have considered this the beginning of a surge of American comedies (Ackworth, 1956: 105), the BBC had begun showing American filmed sitcom The Amos ' $n$ Andy Show in 1955 before ITV began broadcasting (Turnock, 2007: 81). Similarly, the BBC had transmitted US detective series I'm the Law (1953) in 1954, following it later the same year with a filmed detective series made by an independent British company, Fabian of the Yard, produced partially for export purposes (Ibid.: 91). These BBC broadcasts are predated even further by 'Television's first film serial' The Adventures of Rex and Rinty (1935), an imported American film series which chronicled the adventures of Rex the horse and Rin-Tin-Tin, Jr. from April 1949 onwards ('The Scanner,' 1949: 28). Outside drama, American documentary and current affairs series such as Victory at Sea (1952-1953) and Edward R.Murrow's See it Now (1951-1958) were broadcast in Britain from 1952 onwards (Boyd, 2011: 242), showing that the use of American material, mediated through the British sensibilities of the BBC, extended across the television service in both fiction and factual programming.

Considering that 'The BBC knew by the early 1950s that commercial TV was on its way and had started to review its programming in anticipation of the arrival of the new channel' (Cooke, 2003:29), it is striking that the direction that the service began to take with this new material was towards popular American imports and filmed series. However, this is less surprising when the BBC's experience with radio is taken into account, where the popularity of American Forces Radio with the British public during the Second World War combined with the popularity of the BBC's own Forces programme with both military and civilian audiences to suggest the need for the development of 'popular forms of expression, based firmly in British popular culture, that might resemble American practices somewhat but 
Volume 5, Issue 2

September 2012

would not therefore be intrinsically, and dismissably, "American"” (Hilmes, 2003: 24). The result of this was the stranding of post-war BBC radio into the Home Service, the highbrow Third Programme and the populist Light Programme, with the latter attracting over 60 percent of listeners in 1946. Michelle Hilmes has shown that the very popularity of the Light Programme was problematic within the BBC, where it was seen as appealing to the Lowest Common Denominator and associated with American commercial radio, thereby demonstrating that the listening audience needed the paternalistic guidance of the BBC to lift their standards of taste by producing and broadcasting higher quality material than was then broadcast on the Light Programme (Ibid.: 26). This shows the issue at the very heart of the BBC's relationship with American and American-styled product that also lay at the centre of the competition with ITV: whether to embrace the Reithian desire to uplift the public by giving them what they needed as citizens of the British democracy, or whether to give them what they desired as consumers of media.

The BBC Television Service's relationship with American productions is, understandably, complex. Such filmed programmes provided an easy way to fill the schedules, and allowed for the movement of equipment and personnel between studios, and for the preparation of studios for the next live broadcast, particularly at busy times or when time and space were needed to prepare for a large-scale production. The context of American television, particularly by the mid-1950s when the American networks had established themselves and their production patterns, also provided beneficial differences from British programmes. For example, it was a lot easier for American producers to make Westerns, having the necessary infrastructure, not to mention landscape and performers with appropriate skills, in place. Not only that, but American series typically ran to seasons of up to thirty episodes, providing a long-running programme to fill a regular slot and to build a loyal audience in a way that the shorter British serials or single plays could not.

As Rixon notes, during the $\mathrm{BBC}$ monopoly, the American cartoons and short films that were broadcast 'were often shown in the mid to late afternoon, though not particularly aimed at children who often would have been at school at these times' (Rixon, 2006: 119). As one of the purposes of afternoon broadcasts was to provide television retailers' showrooms with something to tune in to in order to demonstrate television sets, this suggests that there were advantages to using American programming for this purpose. In part, it allowed for studios to be set up and used for rehearsals. However, the dynamism of filmed American drama, as opposed to the more intimate presentation of studio-bound British productions, would also provide a visual appeal useful in the selling of television.

While the production of filmed dramas was certainly more expensive than a typical live production and required different skillsets, the limited presence of domestically-produced, Corporation-filmed programming at the BBC was not so much down to cost or lack of technical ability as to ideas of what television should be. There had been a strong emphasis during the 1930s and 1940s on the special style and techniques required for television. The television style combined the liveness of theatre with the intimacy of radio and a slightly 
Volume 5, Issue 2

September 2012

limited version of the visual fluidity of film. Maurice Gorham, Head of the Television Service in 1946, wrote that

the television producer has to deliver a show as transient as a sound broadcast, as elaborate as a film production, with no long run to reward a success, and he has to edit his picture during the action whilst it is being viewed by the audience, and not, as in the cinema, at leisure in the cutting-room, long before the audience sees the film. (Gorham, 1946: 12-13)

Not only this, but there was a basic philosophy of television that considered it to be primarily for the relay of live events from one place to many places, 'an exercise in transmitting an image from one space to another in real time' (Turnock, 2007: 85). Therefore, except where it was necessary out of consideration for budget, scheduling or practicality, as with events happening at too great a distance for live transmission back to the $\mathrm{BBC}$, the use of prerecorded programming was against the ethos of what television was for and what it was best at, rendering it akin to cinema's more restricted and cheaper cousin.

As Geoffrey Lealand's 1984 working paper American Television Programmes on British Screens showed, both ITV and the BBC used popular American programming in late afternoon/early evening slots during the mid-1950s, supporting domestic programming (cited in Rixon, 2006: 18-19). This suggests that there was little difference in the way that the two channels used these imported programmes. Rixon argues that it was the use of a large number of filmed American series in prime-time slots, albeit 'alongside a mix of popular and more serious domestic productions' (Ibid.: 40), that differentiated the ITV companies from the $\mathrm{BBC}$ in its start-up period. He also notes that these series were highly successful, suggesting that this differentiation was effective. The fact that it took until the mid-1960s for the BBC to emulate this practice could be taken to indicate that the use of these pre-recorded programmes was less effective than it seems, but it must be remembered that the very principal of direct competition was one that the BBC disagreed with, and so this delay in emulating ITV's use of prime-time imports suggests rather that this is another indicator of how entrenched opinion within the $\mathrm{BBC}$ was against the commercial, "low-brow" nature of American programming.

\section{The Absence of American Science Fiction Television on British Television}

Despite the presence of a range of pre-recorded American programming on the BBC Television Service during the monopoly, one genre of American television or film that was not shown was Science Fiction. There was certainly an issue with the understanding of Science Fiction within the BBC, and particularly with ideas around the use of the term in relation to fears of Americanisation, as I have discussed elsewhere (Derek Johnston, 2011). This is not because there was no Science Fiction on the BBC Television Service; the first British television Science Fiction dates back to 1938 (Johnston, 2009), while the first British Telefantasy is arguably the telling of two ghost stories by Algernon Blackwood to close the 
Volume 5, Issue 2

September 2012

first evening of regular television broadcasts in 1936. Instead, it dealt very much with the perception of Science Fiction as something indicative of the shallowness of modern American popular culture, as opposed to the European 'scientific romance' tradition, which had a stronger, more established literary lineage in the forms of H.G.Wells, Jules Verne, Robert Louis Stephenson and the like (Johnston, 2011).

Nevertheless, while approaching the genre from a European angle, the $\mathrm{BBC}$ did produce a number of productions that would now be considered to be Science Fiction during the period of the BBC monopoly, with these productions proving both a useful means for testing the possibilities of the medium, and also often proving to be popular with the public. Yet, despite their successful use of Science Fiction, particularly in Nigel Kneale and Rudolph Cartier's Quatermass serials of 1953 and 1955, and their adaptation of Nineteen Eighty-Four in 1954, the BBC had not used any imported filmed American Science Fiction television. This may have been because they believed that it could be done in a more British way that was more suitable to their audiences, as in the views of Kneale and Cartier. Kneale considered The Quatermass Experiment (1953) to be 'something of a critique of science fiction of the time, those terrible American films that were full of flag-waving' (quoted in Petley, 1989: 91) while Cartier emphasised accuracy of research in preparing the serial in order to make it different from 'strip-cartoons and magazine thrillers' (Cartier, 1953).

Whatever the reason, it would be up to ITV to bring American Science Fiction television to Britain. Due to the nature of the organisation of the channel, this would happen in a fairly piecemeal manner. ITV consisted of a number of regional franchises, operated by separate companies, all bound together under the aegis of the Independent Television Authority (ITA). At certain times, all ITV broadcasters would be showing the same programme, across the network, but at other times the regional broadcasters would show their own choice of production. This regionalisation was intended to combat the perceived London-centric nature of the $\mathrm{BBC}$, and to allow for the support and development of regional cultural identity and talent. However, it also meant that programmes imported by one franchise would not necessarily be seen by any other, or that the scheduling of key programmes would be different in different franchises. This area requires further research for its implications on the history of viewing and the cultural significance of individual programmes and broadcasters to be properly understood.

\section{The Fear of Americanisation}

One of the standard discussions around the development of television in Britain was about the loss of British culture in the face of Americanisation. This fear applies not only to television, but has been associated with most, if not all, popular media. For example, Martin Barker has demonstrated that the concerns around comics in the 1950s were largely based around fears of loss of British, or more specifically English, cultural identity and values in the face of American soft power: 'A heritage was at stake: Englishness, good manners, proper English 
language, fine literature. People who have these things know instinctively that anything else is harmful' (Barker, 1984: 82). Similarly, Richard Hoggart in his classic The Uses of Literacy discusses with some dismay the spread of 'a myth-world compounded of a few simple elements which they [the indolent young] take to be those of American life' (Hoggart, 1992: 217), displacing their native cultural expressions. Hoggart's statement also points to a key element of this cultural meeting: that what is important is not the fact of American culture, but rather the idea of what American culture was like.

Rixon has summarised this culture clash in the following terms: 'If some saw British culture as a distinct culture, a mixture of Arnold's sweetness and light with the authentic workingclass culture that Hoggart describes, American culture was all that was crass and popular, pandering to the needs and desires of the masses' (Rixon, 2006: 39). These fears were embodied in the legislation and regulation around the establishment of ITV. As Johnson and Turnock point out, 'although funded by the sale of advertising, the principles under which the new service operated were largely the same as the public service remit governing the BBC' (Johnson and Turnock, 2005: 18). Not only were these principles adhered to, but in a recognition of fears of Americanisation and the possibility of the loss of work in the British television production industry, the ITA established "“a gentleman's agreement" to impose quotas on the amount of programming imported from abroad' (Johnson and Turnock, 2005: 18). However, as we shall, see, this agreement did not prevent the adoption of elements of American style in ITV progamming.

There was a division here between the more populist, apparently more egalitarian viewpoint offered by American cultural artefacts and the more restrained, more "Establishment" values of the productions coming from the BBC. Of course, both BBC and ITV showed material from across the cultural spectrum. But what the idea of American popular culture provided was particularly appealing to the lower classes, as John Fiske has pointed out,

American popular culture in the 1950s and 1960s was eagerly taken up by British working-class youth who found in its flashy streamlining a way to articulate their new class confidence and consciousness. Such symbolizations of their identity were simply not available in 'British' culture which appeared to offer two equally unacceptable sets of alternatives - the one a romanticized cloth-cap image of an 'authentic' traditional working class culture, the other a restrained, tasteful, BBCproduced inflection of popular culture. The commodities produced by the American cultural industries were mobilized to express an intransigent, young, urban, workingclass identity that scandalized both the traditional British working class and the dominant middle classes. The cultural alliance between this fraction of the British working class and their sense of American popular culture was one that served their cultural/ideological needs at that historical moment. (Fiske 1980: 321)

As this makes clear, this was not just an issue related to class, but also to generation; for the younger members of the working classes looking to create an identity for themselves beyond 
that permitted by the older generation, different from that of their parents, American popular culture offered new ways of being. Science Fiction, particularly that which did not draw on the established literary genre of Science Fiction as written by the likes of Welles and Verne, clearly offered a visualisation of this break with the past, utilising the iconography of the new technological age rather than looking back to the past. This fits with Turnock's conception of television in this period as an agent of modernisation and consumerisation in British culture.

However, Turnock suggests that television itself was this agent of modernisation and consumerisation, rather than this being a role dominated by either the BBC or ITV, despite the latter's obvious greater focus on consumerism due to it being funded through the broadcast of advertising. Indeed, the differentiation between BBC and ITV was clear in the way that families would identify with one channel or the other, a practice which persisted, consciously or not, certainly into the 1980s. John Ellis claims that 'households late to television tended to shun ITV in favour of the BBC out of a sense of commitment to civilized, non-Americanized, cultural values' (Ellis, 2005: 40). While there is certainly a convincing aspect to Turnock's argument that the types and content of programmes on both channels were part of this move towards a 'not quite yet fully consumerist society, [but] at least a proto-consumerist one' (Kynaston, 2009: 664), there is also a clear sense that the BBC was attempting to stem this approach to broadcasting, to retain a more evidently "British," high-minded tone, albeit one dominated by certain upper-middle class, paternalistic assumptions that were clearly not popular with all television viewers.

\section{Americanisation, Modernity and the Audience}

Tim O'Sullivan's research into the acquisition and use of television in the 1950s recorded that 'the act of getting a television generally seems to be remembered above all as a sign of progress, a visible sign of joining, or at least of not being left out of, "the new"' (O'Sullivan, 1991: 166). This suggests that television was seen as an indication that the owner was moving into and becoming part of the modern world. Rob Turnock identifies this as part of the modernising of Britain in the post-war period. One of the clearest signs of this modernising was to be found in consumption, in the move away from austerity and into a period of modernity signalled by possessions, and Turnock shows that television had a key role in this, in demonstrating to its widening audience the possibilities that were becoming open to them, the ways of living, and the potential possessions. Most obviously, commercial 'television explicitly made consumerism visible' through the broadcast of advertisements (Turnock, 2007: 143), but it also

presented a range of lifestyles and new forms of behaviour including, but not necessarily restricted to, social mobility, individual and personal freedom, material comfort and convenience. This new behaviour often involved the conspicuous display of (and in some cases relied on) material goods and commodities. In a range 
Volume 5, Issue 2

September 2012

of programmes material goods and lifestyle were linked and potentially made desirable. (Turnock, 2007: 148)

So not only did the medium show 'what to consume and how to consume it (and in many cases how to get it)' (Turnock, 2007: 158,), but they did this in a way that encouraged movement beyond the individual's existing class and social conditions,

appealing instead to gender and age and, in doing so, offering the possibility of social mobility. Some programmes provided potential role models for the first time in the $1950 \mathrm{~s}$ and 1960s. They could offer and suggest models for appropriate types of behaviour in particular situations. (Turnock, 2007: 158)

These new lifestyles extended across the generations, but they would have had a particular influence on the young, who were experiencing full employment, an increase in wages in real terms, and no national service, providing them with more free time and more disposable income to spend in it. This is one of the reasons why, despite the term having been around since the start of the 1940s, it is 'the generally-accepted view that teenagers began in the mid1950s' (Savage, 2007: xv). This is when they began to have the economic power to make themselves felt within society and to create their own identities and subcultures through consumption. Part of that consumption was, inevitably, the media, and while there would have been very few of even this newly-wealthy generation who could have afforded their own television set, and somewhere to put it, this section of the population became important to appeal to commercially, as well as being a sector of the audience that needed to be appealed to in public service terms of forming a rounded citizen.

\section{Embracing the Fear: Americanisation and Popularism}

From the audience, we now turn to the programmes themselves. The BBC had pursued opportunities for exploiting its television productions through sales abroad, establishing a 'transcription unit' in 1952 expressly for this purpose, perceiving the possibilities this presented for adding to the income from the licence fee. However, the BBC's own productions were still overwhelmingly live, and therefore hard to sell abroad. Issues between the BBC and the actors' union Equity around the payment for the recording of actors' performances discouraged recording productions for repeat showings or selling overseas. Plans to broadcast The Quatermass Experiment in Canada reached the stage that the production was scheduled for CBLT (Murray, 2006: 32). However, technical issues with the telerecording of the live broadcast meant that it was deemed unsuitable for transmission, so not only were plans for the Canadian transmission abandoned, but telerecording of all episodes after the first two was also dropped (Rutherford, 1953). One of the most successful examples of the selling of British television overseas from the monopoly period was not an in-house production at all, but instead the remarkable success of Annette Mills' Muffin the 
Volume 5, Issue 2

September 2012

Mule (1946-1955), which was praised for selling 26 filmed episodes to American television, thereby bringing in valuable trade dollars to the British economy, and earning Mills the title of 'The Walt Disney of Britain' from one newspaper (Anon. 1950). This celebration of British television success on the international stage fits partly with the sense of a better, consumerist future that Rixon, among others, argues was part of the appeal of American cultural products as 'an escape from the last days of the empire and the austerity of post-war Britain' (Rixon, 2006: 41). However, it also fits with ideas that are more in-line with the BBC's overarching ethos in that it suggested that Britain was still a cultural power, even if it was diminished in other ways, and there is the possibility that being seen as a "soft" cultural power was actually more suitable to the new, post-war world.

Before any actual imported film of Science Fiction productions from the US, the BBC had staged its own production of the American play 'Mystery Story' (Sunday-Night Theatre, 1950-1959) in 1952, adapted for television by BBC staff writer Nigel Kneale, whose seminal The Quatermass Experiment would be broadcast the following year. The Radio Times listing for the production actually describes it as 'a new American play by Stanley Young' (Anon., 1952: 38). Not only was this the staging of an American script by 'a prominent New York publisher,' but the Radio Times' television previewer 'The Scanner' made the point that 'Mystery Story is set in America and, with the exception of Maurice Colbourne who has spent many years in Canada and the United States, all the principal parts will be played by Americans or Canadians' ('The Scanner', 1952: 36). The play concerned the presence of an alien on Earth, and the use of advanced mental powers, which are focused through the emotional lens of a college football game and result in a death. It is interesting to note that there are some similarities with this conception of psychic amplification through groups of people to be found in Kneale's own work, particularly his Quatermass serials. 'Mystery Story' received mixed audience responses, with N.J.Shaw calling it 'a delightful change from the usual run of plays', while J.I.M.O'Brien considered it 'trash', 'drivel' and 'an attempt to play on the emotions of the public' (Shaw and O'Brien, 1952 :38). Neither of these letters published in the Radio Times mentioned the Americanness of the play, although Kelly Boyd has pointed out that there were a number of negative comments made regarding other American scripts produced for BBC television based on their national origin. Yet Boyd argues that 'the choices made suggest the $\mathrm{BBC}$ employed foreign content not only to bring more variety to its schedule, but also to reinforce the strength of British culture in a period when the rise of the United States implied a decline in British power' (Boyd, 2011: 233). In other words, by using American material in a British way, surrounded by programming that was British, showed that British culture was still able to master and control American product, and to make something different of it, something more British.

The importation of actual American recorded Science Fiction, however, would not occur until the launch of ITV in 1955, and this first programming would not actually be shown until a year after the network was launched. Johnson and Turnock point to ITV's achievement of financial success after a poor beginning as being down to a number of causes (Johnson and 
Volume 5, Issue 2

September 2012

Turnock, 2005: 21). Firstly, the extension of the network as more transmitters went online and more of the regional franchises began transmissions meant that there were more people able to receive the channel. With more people able to receive television, more of them were likely to pay for a new television set; these people would then provide an opportunity for visiting friends, family and neighbours to experience ITV for themselves in order to decide whether they too wanted to accept the expense of a new set capable of receiving the channel. Along with this widening of the potential audience, this period also saw 'a change in programming policy which moved away from programming that was regarded as more "serious", towards more popular entertainment such as lavish quiz shows' (Johnson and Turnock, 2005: 21). The rise in audience figures meant more advertiser confidence, which meant more income for the franchises.

The first American Science Fiction television production shown in Britain was Adventures of Superman (1952-1958), shown by the ITV network from February 1956 at 7pm on Mondays, with each episode emphasising the alien nature of the lead character by introducing him as 'strange visitor from another planet, who came to Earth with powers and abilities far beyond those of mortal men.' Superman was not a new character to British audiences, having appeared on the cinema screen in serials such as Superman (1948, UK screening 1949, condensed feature version 1953) and Atom Man Versus Superman (1950, UK screening 1951) and in the feature-length Superman's Peril (1954, UK screening 1954) and Superman Flies Again (1954, UK screening 1956), both condensed from previous serials. The character was also familiar enough from comics to be picked out by George Orwell as emblematic of the sort of sensationalist American comic book that he disapproved of in his essay 'Riding Down to Bangor' (1946). However, in many ways it was the television series that had the strongest impact in Britain, as was made clear thirteen years later, in the Monty Python's Flying Circus 'Bicycle Repair Man' sketch, first broadcast on 19 October 1969 in the third episode of the first series (Chapman et al, 1989: 320). This featured a world of Supermen, all wearing a copy of the George Reeves Superman outfit, complete with the identifying ' $S$ ' shield, all of whom were at the mercy of damaged bicycles which could only be repaired by Bicycle Repair Man, the secret identity of F.G. Superman. The George Reeves live-action series was not the only presence of the alien superhero on British screens, as viewers could also see the Fleischer Studios animated Superman (1941-1943), at least on regional ITV franchise Associated Television, from Saturday 7 April 1956 in the late afternoon. Together, these programmes provided light, action-filled entertainment, and also a conception of the lone, superpowered hero which went beyond the clubland adventurer like Bulldog Drummond or Dick Barton to suggest a new form of personal power and responsibility to reshape society.

Other imported American Science Fiction followed, sometimes networked, sometimes only shown in specific regions. So it was ATV Midlands that showed the serious-minded anthology series Science Fiction Theatre (1955-1957), beginning the night after the first screening of Adventures of Superman, with a separate franchise, Associated Rediffusion, also 
Volume 5, Issue 2

September 2012

broadcasting episodes. Action-adventure series Jet Jackson, the Flying Commando (19541958, originally titled Captain Midnight before syndication) was shown across the network from 20 April 1959 at $6.40 \mathrm{pm}$ on Mondays, suggesting that it was seen as a transitional programme from the post-school television intended for children into the more adult programmes of prime-time slots. While this is not a large selection of programming in the context of the first five years of ITV broadcasting, it does demonstrate that the channel and its constituent franchises were not simply looking to American Science Fiction to appeal to children. Superman and Jet Jackson may have filled this purpose, but the other imported Telefantasy series took a more adult approach, with their broadcast later in the evening, at 7:05pm or 7:30pm for Science Fiction Theatre, and, to look beyond Science Fiction at the wider field of Telefantasy, 7:30pm or $11 \mathrm{pm}$ for episodes of Horror series Inner Sanctum (1954), which was shown from 3 October 1955.

It seems appropriate to take 1960 as a turning point for the use of imported Science Fiction television in Britain, as this marked its first use by the BBC, which showed the thirty-eight episodes of the serious-minded Men Into Space (1959-1960) from 9 July 1960 in the 5pm Saturday slot. This scheduled the programme, which aimed to tell tales based on the extrapolated realities of space travel, against a variety of action and adventure shows across the ITV regions: Adventures of a Jungle Boy (1957) on ATV at 5.15, Ivanhoe (1958) on ABC Midlands at 5.15, Hawkeye (1957) on ABC Northern at 5.15, The Adventures of Robin Hood on Anglia at 5 and on Southern at 5.15, The Buccaneers (1956-1957) at 5.15 on South Wales and West of England, Tales of the Texas Rangers (1955-1959) on Scottish Television at 5, and The Adventures of the Scarlet Pimpernel (1956) on Ulster at 5.15, while Tyne Tees had My Friend Flicka (1955-1958) also at 5.15. It is immediately obvious that the BBC's broadcast would have pre-empted most of these programmes simply by being broadcast at $5 \mathrm{pm}$. The ITV broadcasters responded to this challenge, largely, by moving these programmes forward to 5pm, starting on 6 August 1960. It is also notable that Men Into Space took up a slot between two sporting programmes: Motor Cycling at 4.30 and Test Match at 5.25, although it would be directly followed by Billy Bunter of Greyfriars School (1952-1961) from 30 July 1960. When Doctor Who (1963-1989) began broadcasting in November 1963 it was in the 5.15 slot, putting it up against the seven-part domesticallyproduced children's Science Fiction serial Emerald Soup (1963) across all ITV regions except for South Wales and the West of England, which was showing The Adventures of Robin Hood.

By pitting a programme which aimed for a level of scientific veracity and seriousness in exploring the potential, if fictional, future of manned space flight against action-adventure swashbucklers, the scheduling of Men Into Space also demonstrates the different approaches of the BBC and ITV in adopting American television programmes and practices. The BBC sought out material, in this case, that corresponded to their ideas of Science Fiction in shunning the more 'comic-book' elements of the genre. Meanwhile ITV adopted an American style for their own productions as another way of associating the commercial 
Volume 5, Issue 2

September 2012

broadcaster with the popular conception of American popular culture, at the same time as the programming aided the absorption of those traits into British culture. In other words, a merging of British and American television was sought in both cases, though through two different approaches. Not only might this make the American style more palatable to certain parts of the British audience, but it also offered the possibility of then selling this new, transatlantic product to the American broadcasters. As Jonathan Bignell records, Lew Grade's ATV / ITC companies, which were prominent in adopting American practices, 'were praised for competing with Hollywood at its own game, but were also tainted by suspicions of Americanization' (Bignell, 2005: 59). Indeed, today the action-adventure series of the late 1950s and particularly the 1960s, like The Saint or The Avengers, have been seen as 'very much a case of British television remaking and remarketing genres that had originally been imported from the USA' (Turnock, 2007: 156).

The development of this transatlantic style was helped by a number of factors. Firstly, with the establishing of ITV had come the need for trained personnel; while many were 'poached' from the BBC with offers of higher pay and newer facilities, others were drawn from the wider global television profession, particularly from Canada, as 'Canadians did not need work permits. There was not only a great deal of ready-made material to import from North America, there was also a group of trained people to supplement the English BBC-trained directors' (Shubik, 2000: 9). Secondly, the blacklisting of numerous writers in the United States by the House Un-American Activities Committee meant that there were seasoned professionals in dire need of work which they could not find in their own country, and so available somewhat more cheaply than they would otherwise have been (see e.g. Neale, 2005: 73).

A key ITV example of this new form of transatlantic production was the filmed series The Invisible Man (1958-1959). This turned Wells' tragic megalomaniac into a scientist turned invisible by his own experiments, who then turns to being a spy for the British Government while they support his experiments to make himself visible again. Ironically enough, at a time when British scientists were being tempted to the US by the prospects of better funding and resources, the series' lead character was an American scientist working for the British, thereby also providing an American lead identification figure for the US market.

Many of the other transatlantic series that were produced in the 1950s and early-1960s were produced by ATV, which broadcast The Invisible Man, although Steve Neale has pointed out that many of these transatlantic productions actually had American companies directly involved in their production and distribution (Ibid.: 80-81). Jonathan Bignell has demonstrated the significance of what he calls the 'mid-Atlantic framing' of programmes to ATV productions in particular, suggesting that this extended even to the highly-successful variety show Sunday Night at the London Palladium (1955-1967) (Bignell, 2005). The possibilities of selling-on drama series such as The Invisible Man to American, and other, broadcasters were improved by their form. Shot on film, rather than videotape, there were no issues with different video standards, and their production for a commercial broadcaster 
Volume 5, Issue 2

September 2012

meant that their narratives were structured for broadcast with commercial breaks. Bignell argues that 'In the production organization of programmes, and in some of their aesthetic choices (like casting American performers), hybrid components represent concrete instances of negotiation with Britishness and Americanness' (Ibid.: 64). In addition to this, Neale points to the success of these shows, referring specifically to the reception of The Adventures of Robin Hood, as being partially due to their 'appeal to a crossover audience, to adults and families as well as children' (Neale, 2005: 74). It is particularly interesting to note this in relation to the creation in 1963 of Doctor Who as a programme intended specifically to reach this crossover audience, bridging the gap between Grandstand (1958-2007) and Juke Box Jury (1959-1990) (Chapman, 2006: 18).

\section{Conclusion}

While the very small amount of American Science Fiction on ITV during this period means that it cannot be taken as a major indicator of trends on its own, it does work alongside the changing approach to television seen within the ITV companies. It forms part of their differentiation of themselves from the BBC by means of embracing the fast-paced, exciting style of American television. What is interesting here is that domestic ITV Science Fiction productions seem to fit very much with the style of BBC Science Fiction established before the introduction of television competition in Britain. Maybe calling this a 'style' is suggesting too much consistency, because what is most striking about the development of the British genre before the introduction of ITV is that it embraced a range of approaches to the genre, and a range of sub-genres. So there were serious, issue-led plays, gripping adult serials, fastmoving children's serials with an educational bent, scientific romances, alternate universes, exploration and invasion, stodgily-staged productions and those that sought to experiment with the possibilities of television technique. Productions made for ITV initially followed much the same pattern for their Science Fiction, whether adapting the same texts, or producing similar dramas and serials. However, at the same time, ITV was embracing the fast-moving, action-adventure filmed series in such spectacular swashbucklers as The Adventures of Robin Hood, Ivanhoe, The Adventures of Sir Lancelot (1956-1957) and The Buccaneers and successfully exporting it back to America, stamped with a sense of authentic British character and history. Like Superman, these 'strange visitors from another planet,' planet America, had been successfully embraced and repackaged, reshaped by their environment. The suit, hat and glasses that turned Kryptonian Kal-El into mild-mannered reporter Clark Kent were emulated in the reforming of American styles of television with British narratives, accents and actors swashbuckling their way across the screen, even when the lines were written by Americans.

All of these attempts at differentiation through populism may have been in vain, though. Chris Hand has concluded from research into the patterns of television acquisition in the mid1950s that it was 'the combined effect of the launch of ITV and the introduction of choice of 
Volume 5, Issue 2

September 2012

programming' which had the most influence 'on the decision to acquire a television set and on the timing of acquiring a television set' (Hand, 2007: 76). This suggests that it was less the character of the differentiated programming that ITV offered that contributed to these decisions, but more the fact that it offered programming that was different from that offered by the BBC. There was no need for ITV to establish an Americanised identity; it simply had to not be the $\mathrm{BBC}$.

\section{References}

Ackworth, M. (1956) 'Yankee Doodle TV Dandy: Some American imports for British viewers' in Baily, K. (Ed.) The Television Annual for 1957. London: Odhams Press Ltd. Anon. (1950) 'Walt Disney of Britain,' News Review, 6 April.

Anon. (1952) 'Mystery Story’ listing, Radio Times, 15 August.

Barker, M. (1984) A Haunt of Fears: The Strange History of the British Horror Comics Campaign. London: Pluto Press.

Bignell, J. (2005) 'And the Rest is History: Lew Grade, Creation Narratives and Television Historiography' in Johnson, C. and Turnock, R. (Eds.) ITV Cultures: Independent Television Over Fifty Years. Maidenhead: Open University Press

Boyd, K. (2011) ‘Cowboys, Comedy and Crime,' Media History. 17:3, pp.233-251.

Cartier, R. (1953) Letter to C. Moodie, Air Ministry, 12 June 1953, BBC Written Archive Centre T5/418.

Chapman, J. (2006) Inside the TARDIS: The Worlds of Doctor Who. London: I.B.Tauris.

Chapman, G., Cleese, J., Gilliam, T., Idle, E., Jones, T. and Palin, M. (1989) Monty Python's Flying Circus: Just the Words, Volume 1. London: Methuen.

Cooke, L. (2003) British Television Drama: A History. London: British Film Institute.

Ellis, J. (2005) 'Importance, Significance, Cost and Value: Is an ITV Canon Possible?' in Johnson, C. and Turnock, R. (Eds.) ITV Cultures: Independent Television Over Fifty Years. Maidenhead: Open University Press.

Fiske, J, (1980) Television Culture. London: Routledge.

Gorham, M. (1946) 'Restarting Television,' B.B.C. Quarterly, vol.1, no.1.

Hand, C. (2007) 'The Advent of ITV and Television Ownership in Lower Income Households: Correlation or Causation?' Journal of British Cinema and Television, vol.4, no.1, pp.67-79. 
Volume 5, Issue 2

September 2012

Harrison, J. (2005) 'From Newsreels to a Theatre of News: The Growth and Development of a Independent Television News' in Johnson, C. and Turnock, R. (Eds.) ITV Cultures:

Independent Television Over Fifty Years. Maidenhead: Open University Press.

Hilmes, M. (2003) 'British quality, American chaos: Historical dualisms and what they leave out,' The Radio Journal, vol.1, no.1, Spring, pp.13-27.

Hoggart, R. (1992) The Uses of Literacy. London: Penguin.

Johnson, C. and Turnock, R. (2005) 'Introduction: Approaching the Histories of ITV' in ITV Cultures: Independent Television Over Fifty Years. Maidenhead: Open University Press.

Johnston, D. (2009) 'Experimental Moments: R.U.R. and the Birth of British Television Science Fiction,' Science Fiction Film and Television, 2.2.

Johnston, D. (2011) 'The BBC Versus Science Fiction! The Collision of Transnational Genre and National Identity in British Television in the Early 1950s' in Leggott, J. and Hochscherf, T. (Eds.) British Science Fiction Film and Television: Critical Essays. London: McFarland.

Kynaston, D. (2009) Family Britain 1951-1957. London: Bloomsbury.

Murray, A. (2006) Into the Unknown: The Fantastic Life of Nigel Kneale. London: Headpress.

Neale, S. (2005) 'Transatlantic Ventures and Robin Hood' in Johnson, C. and Turnock, R. (Eds.) ITV Cultures: Independent Television Over Fifty Years. Maidenhead: Open University Press.

Orwell, G. (1994 [1946]) 'Riding Down to Bangor,' Essays, London: Penguin.

O'Sullivan, T. 'Television Memories and Cultures of Viewing, 1950-65' in Corner, J. (Ed.)

Popular Television in Britain: Studies in Cultural History. London: British Film institute.

Petley, J. (1989) 'The Manxman,' Monthly Film Bulletin, March 1989.

Rixon, P. (2006) American Television on British Screens: A Story of Cultural Interaction. Basingstoke: Palgrave Macmillan.

Rutherford, N. (1953) Memo to P.O.Tel, 23 November 1953, BBC WAC T5/418.

Savage, J. (2007) Teenage: The Creation of Youth 1875-1945. London: Pimlico.

'The Scanner.' (1949) 'Talk of the Week,' Radio Times, 15 April.

'The Scanner.' (1952) 'Talk of the Week,' Radio Times, 15 August.

Shaw, N.J. and O'Brien, J.I.M. (1952) 'Viewers Write to the "Radio Times," Radio Times, 29 August.

Shubik, I. (2000) Play for Today: The Evolution of Television Drama. Manchester: Manchester University Press. 
Volume 5, Issue 2

September 2012

Turnock, R. (2007) Television and Consumer Culture: Britain and the Transformation of Modernity. London: I.B.Tauris.

Bibliographic note: Schedule information sourced from The Times digital archive.

\section{Teleography}

Adventures of a Jungle Boy. (1957) U.K.: Kenya Productions/Gross-Krasne Productions.

The Adventures of Robin Hood. (1955-1960) U.K.: Sapphire Films/Incorporated Television Company/Yeoman Films Ltd.

The Adventures of Sir Lancelot. (1956-1957). U.K.: Sapphire Films/Incorporated Television Company.

The Adventures of the Scarlet Pimpernel. (1956). U.K.: Incorporated Television Company/Towers of London Productions.

Adventures of Superman. (1952-1958) U.S.A.: Superman Inc.

The Amos 'n Andy Show. (1951-1953) U.S.A.: CBS Television Network.

Battlestar Galactica. (2003-2009) U.S.A./U.K./Canada: U.S.A. Cable Entertainment/British Sky Broadcasting/NBC Universal Television/R\&D TV/David Eick Productions/Universal Media Studios/Stanford Pictures.

Billy Bunter of Greyfriars School. (1952-1961) U.K.: British Broadcasting Corporation. The Buccaneers. (1956-1957) U.K.: Sapphire Films/Incorporated Television Company. Buffy the Vampire Slayer. (1997-2003) U.S.A.: Sandollar Television/Kuzui Enterprises/Mutant Enemy/20th Century Fox Television.

Children's TV on Trial. (2007) U.K.: British Broadcasting Corporation.

Crusade. (1999) U.S.A.: Babylonian Productions/Turner Network Television.

Doctor Who. (1963-1989) U.K.: British Broadcasting Corporation.

Emerald Soup. (1963) U.K.: ABC Weekend Television.

Fabian of the Yard. (1954) U.K.: British Broadcasting Corporation.

Firefly. (2002-2003) U.S.A.: Mutant Enemy/20th Century Fox Television.

Grandstand. (1958-2007) U.K.: British Broadcasting Corporation.

Hawkeye. (1957) Canada/U.K.: Normandie Productions/Incorporated Television Company. I Love Lucy. (1951-1957) U.S.A.: Desilu Productions.

I'm the Law. (1953) U.S.A.: Television Corporation of America/Cosman Productions. Inner Sanctum. (1954) U.S.A.: Galahad Productions. 
Volume 5, Issue 2

September 2012

The Invisible Man. (1958-1959) U.K.: Incorporated Television Company.

Ivanhoe. (1958) U.K.: Sydney Box Productions.

Jake 2.0. (2003-2004) U.S.A./Canada: Viacom Productions/Roundtable

Entertainment/Matthews Scharbo Productions/Silent H Productions/Jake Productions.

Jet Jackson, the Flying Commando aka Captain Midnight. (1954-1958) U.S.A.: Screen Gems Television.

Juke Box Jury. (1959-1990) U.K.: British Broadcasting Corporation.

Knight Rider. (1982-1986) U.S.A.: Universal TV/Glen A Larson Productions.

Knight Rider. (2008-2009) U.S.A.: Dutch Oven/Universal Media Studios.

Lost. (2004-2010) U.S.A.: Bad Robot/Touchstone Television/ABC Studios/Grass Skirt Productions.

Lost in Space. (1965-1968) U.S.A.: Jodi Productions Inc./20th Century Fox Television/Van Bernard Productions/Irwin Allen Productions/Columbia Broadcasting System/Space Productions.

Men Into Space. (1959-1960) U.S.A.: ZIV Television Programmes.

Monty Python's Flying Circus. (1969-1974) U.K.: British Broadcasting Corporation/Python (Monty) Pictures.

- 'How to Recognise Different Types of Trees from Quite a Long Way Away,' Monty Python's Flying Circus. Episode 1.03. Dirs. John Howard Davies, Ian MacNaughton. BBC. 1969, October 19.

Muffin the Mule. (1946-1955) U.K.: Parthian Productions.

My Friend Flicka. (1955-1958) U.S.A.: American Broadcasting Company/20th Century Fox Television/Columbia Broadcasting System/National Broadcasting Company.

Nineteen Eighty-Four. (1954) British Broadcasting Corporation.

The Quatermass Experiment. (1953) U.K.: British Broadcasting Corporation.

Quatermass II. (1955) U.K.: British Broadcasting Corporation.

Science Fiction Theatre. (1955-1957) U.S.A.: Ivan Tors Production.

See It Now. (1951-1958) U.S.A.: Columbia Broadcasting System.

The Six Million Dollar Man. (1974-1978) U.S.A.: Silverton Productions/Harve Bennett Productions/Universal TV.

Stargate SG-1. (1997-2007) U.S.A./Canada: Gekko Film Corp./Stargate SG-1 Production Inc./Sony Pictures Television/Kawoosh! Productions/Double Secret Productions/MGM Worldwide Television Productions. 
Volume 5, Issue 2

September 2012

Sunday Night at the London Palladium. (1955-1967) U.K.: Associated Television.

Sunday-Night Theatre. (1950-1959) U.K.: British Broadcasting Corporation.

- 'Mystery Story,' Sunday-Night Theatre. Episode 3.33. Dir. Anon. BBC. 1952, August 17.

Tales of the Texas Rangers. (1955-1959) U.S.A.: Screen Gems Television.

Tru Calling. (2003-2005) U.S.A./Canada: Fox Television Network/20th Century Fox Television/Millennium Canadian Productions Ltd./Original Television/"Oh That Gus!"/Tru Calling Productions.

Victory at Sea. (1952-1953) U.S.A.: The United States Navy/National Broadcasting Company.

The X-Files. (1993-2002) U.S.A./Canada: 20th Century Fox Television/Ten Thirteen Productions/X-F Productions.

\section{Filmography}

The Adventures of Rex and Rinty. (1935) Dirs. Ford Beebe, B. Reeves Eason. U.S.A.: Mascot Pictures.

Atom Man vs. Superman. (1948) Dir. Spencer Gordon Bennet. U.S.A.: Columbia Pictures Corporation.

Superman. (1941-1943) Dirs. Dan Gordon, Dave Fleischer, Seymour Kneitel. U.S.A.: Fleischer Studios/Famous Studios.

Superman. (1948) Dirs. Spencer Gordon Bennet, Thomas Carr. U.S.A.: Columbia Pictures Corporation.

Superman Flies Again. (1954) Dirs. George Blair, Thomas Carr. U.S.A.: Superman Inc. Superman's Peril. (1954) Dirs. George Blair, Thomas Carr. U.S.A.: Superman Inc.

\footnotetext{
${ }^{1}$ Opening title narration for Adventures of Superman (1952-1958)
} 